\title{
Incomplete rhizogenesis and necrosis treated with PBS® HP cement synthetic barrier: case report
}

\begin{abstract}
Introduction: Endodontic treatment of necrotic permanent teeth with incomplete rhizogenesis requires professional expertise, especially when the patient is an adult, with a history of trauma. Calcium hydroxide specification has drawbacks. Synthetic apical barriers with a variety of materials were proposed as alternatives to the traditional method of treating necrotic teeth with incomplete rhizogenesis. HP PBS cement mainly contains the biocompatibility and bioactivity properties, which enable it to be used in these cases as a single shutter material in a single session.
\end{abstract}

Objective: The purpose of this study was to observe the rehabilitation and regeneration of periapical tooth tissues with necrotic incomplete rhizogenesis after endodontic obturation using PBS ${ }^{\circledR}$ HP non-conventional biological cement.

Case report: This report presents the case of an adult patient with apical lesion, fistula and incomplete rhizogenesis in the tooth 2.2. The initial diagnosis was by periapical radiography. The mechanical chemical preparation of the root canal and filling with PBS ${ }^{\circledR}$ HP cement was performed as a single element. Six months later, the patient underwent re-preservation, which identified the rehabilitation of the tooth and periapical tissues.

Conclusion: $\mathrm{PBS} \circledast$ HP cement has determined regeneration of periapical tissues and may be indicated as a synthetic barrier in necrotic teeth with incomplete rhizogenesis.

Keywords: root canal therapy, endodontics, biocompatible materials, periapical, suppurative periodontitis, apical foramen, tooth apex, periapical granuloma

\author{
Volume 9 Issue 3 - 2018
}

\author{
Sérgio Ribeiro da Silva,' Idiberto José \\ Zotarelli Filho, ${ }^{2}$ Jose Dias da Silva Neto' \\ 'Department of Applied Health Sciences, SapucaíValley \\ University, Brazil \\ ${ }^{2}$ Institute of Biosciences, Humanities and Exact Sciences (Ibilce), \\ São Paulo State University, Brazil
}

\begin{abstract}
Correspondence: Jose Dias da Silva Neto, Programa de Mestrado Profissional em Ciências Aplicadas a Saúde, UNIVÁS, Pouso Alegre-MG, Av. Prefeito Tuany Toledo 470, Fátima I, CEP 37550-000, Brazil, Tel 035-344-99248; 553-598-883-6910, Email jdendod@yahoo.com.br
\end{abstract}

Received: May 28, 2018| Published: June 14, 2018

\section{Introduction}

Endodontic treatment of necrotic permanent teeth with incomplete rhizogenesis requires specific and complex clinical procedures. This endodontic modality is associated with young and adult patients with necrotic teeth before complete root formation. Causes are linked to carious lesions and trauma. ${ }^{1}$ In addition to necrosis, these teeth present thin walls with greater susceptibility to fracture and the broad lumen of the apical foramen makes it difficult to maintain the obturator material within the root canal, which compromises the long-term success of the treatment. ${ }^{2,3}$ Dental maturity is assessed by the dental specialty (endodontics) through several classification systems for the degree of root formation and maturation. ${ }^{4}$ The Cvek classification describes the five stages of root development: $\mathrm{I}=<1 / 2$ root length, $\mathrm{II}=1 / 2$ root length, $\mathrm{III}=$ root length $2 / 3, \mathrm{IV}=$ open apical foramen and near full length of the root and $\mathrm{V}=$ closed apical foramen and complete root development. ${ }^{5}$ Few studies have examined the root development stage in relation to the frequency of teeth with open apices and necrotic pulp. ${ }^{6}$ In the physical trauma of a tooth, with fracture or not, the pulp may recover completely or necrotic, depending on the intensity of the hemorrhage established after trauma and / or the stage of root development. ${ }^{7}$ Pulp necrosis occurs when blood flow to the dental pulp is interrupted and oxygen depletion occurs because of failure of blood circulation in the pulp tissue. In this situation, necrosis is progressive degeneration, and the tooth can remain asymptomatic. ${ }^{8}$ When the pulp undergoes necrosis before complete rhizogenesis, the dentin formation ceases, the root growth is interrupted, the canal remains broad and the root apex is open. ${ }^{9}$ The infected canal induces local immune reaction called the periradicular lesion visualized by radiography. ${ }^{10}$ Chronic inflammatory lesions in tissues that surround and relate directly to the tooth apex are generally identified as chronic periapical lesions. One can also use the term chronic periapicopathy as a synonym. Among these chronic periapical lesions are periapical granuloma, chronic periodontal cyst and chronic dentoalveolar abscess. ${ }^{11}$ It is imperative to perform complete removal of all necrotic tissue and apexification. Calcium hydroxide has been widely used to induce a hard tissue barrier at the apex of the tooth (apexification). Despite its successful results, there are numerous flaws reported. The main deficiencies are time required (6-18 months), incomplete apical hard tissue barrier by vascular inclusions and loss of organic and inorganic component of dentin due to calcium hydroxide. ${ }^{12}$ Synthetic apical barriers with a variety of materials were proposed as alternatives to the traditional method of treating necrotic teeth with incomplete rhizogenesis. ${ }^{13}$ It is necessary to use cements that have some basic requirements, such as: hermetic sealing, biocompatibility and, moreover, they must be precursors in the formation of carbonated apatites that promote biomineralization, which leads to the formation of a layer of periodontal ligament at the interface bone- dentin. ${ }^{14,15}$ Portland cement used in civil construction is the basis of these biological cements, and its raw material is limestone. Among the biological cements, the first one to appear in dentistry was the MTA ${ }^{\circledR}$ (Agredado Trioxide Mineral), composed of common Portland cement plus bismuth oxide, which is a radiopacifying agent. ${ }^{16}$ Recently, studies have determined the development of a cement with the same base of MTA ${ }^{\circledR}$, but with additives additions (natural elements responsible for cement resistance) Cement PBS ${ }^{\circledR}$ (Pozolana Biologico Silva). ${ }^{17-19}$ The objective of this study was to observe the regeneration of periradicular tissues after endodontic obturation of necrotic tooth with incomplete rhizogenesis using PBS ${ }^{\circledR}$ HP cement. 


\section{Case report}

The present study refers to a case report of a tooth with incomplete rhizogenesis necrosed with periapical lesion, element 2.2. Patient F., male, leucoderma, 36 years old, was referred to the Dentistry Clinic of the Brazilian Association of Dentistry, in the Specialization course in Endodontic Latu sense of the Postgraduate Program at the University of Vale do Sapucaí, Pouso Alegre, Minas Gerais General, Brazil. After performing the exams for endodontic treatment, the treatment was proposed to the patient, and then he accepted and signed the Free Consent Term (ICF). Clinical examination revealed fistula in the tooth region 2.2. The periapical pathology was observed in the radiographic examination (Figure 1) through the installation of a gutta percha cone in the fistula. Clinical procedure: infra-orbital anesthesia with anesthetic Articaine 100 DFL ${ }^{\circledR}$ - Articaine hydrochloride + Epinephrine - 1 cartridge, with $30 \mathrm{G}$ Unoject ${ }^{\circledR}$ short hypodermic needle; absolute isolation of the operative field, using $\mathrm{KSK}{ }^{\circledR}$ clamp number 212, Madeitex ${ }^{\circledR}$ rubber sheet; Coronary opening, performed with a 1016 HL KG Sorensen ${ }^{\circledR}$ drill bit and Kavo ${ }^{\circledR}$ high-speed motor coupled to the intra-dental Gnatus ${ }^{\circledR}$ dental system. Pulp node removal through Gnatus ${ }^{\circledR}$ ultrasound. Irrigation abundant with $2.5 \%$ Sodium Hypochlorite throughout the protocol. Crown-down instrumentation according to the apparent length of the tooth was used ProDsign Logic Easy ${ }^{\circledR} 25.05$ files. Odontometry through periapical radiography due to the amplitude of the apical region (tooth with incomplete rhizogenesis). The chemical-mechanical preparation was started with Easy Logic 25.05 from Easy ${ }^{\circledR}$ of Nickel-Titanium with memory control, with the aid of the Easy Endo SI engine from Easy®.

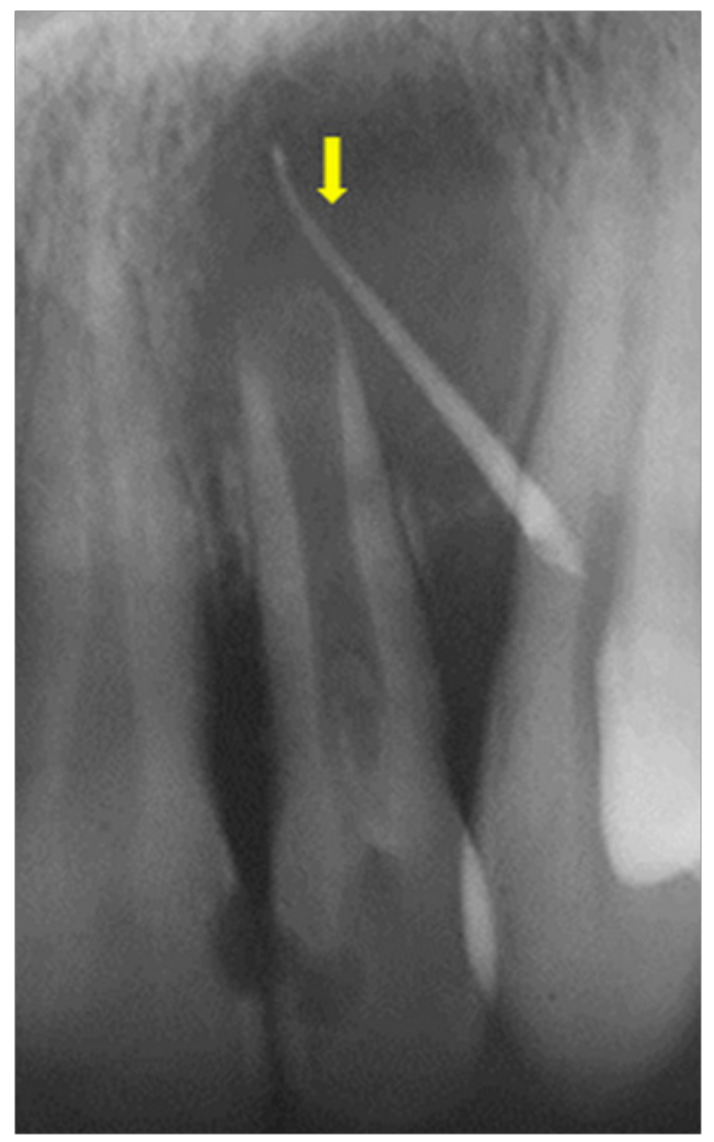

Figure I Initial radiograph of tooth 2.2 showing periapical lesion and incomplete rhizogenesis.
The movement performed was reciprocating, determined by the motor software in dynamic "brushstroke", due to the fragility of the root walls. To conclude this session, the PUI (Passive Ultrasonic Irrigation) protocol with Gnatus ${ }^{\circledR}$ ultrasound and endodontic insert was used, using EDTA-T (Ethylene diamine tetraacetic acid surfactant) of Formule and Action for 330 -second series and abundant irrigation with Sodium Hypochlorite to $2.5 \%$ and stirring thereof in 3 sets of 30 seconds. Final irrigation with distilled water. Drying with Tanary ${ }^{\circledR}$ absorbent paper cone. The channel was filled with non-conventional PBS ${ }^{\circledR}$ HP cement; cement manipulation was performed on Duflex ${ }^{\circledR}$ glass plate and spatula 24 in the "putty" consistency, the ratio of powder and sterile distilled water was $1 / 2$. The PBS ${ }^{\circledR}$ HP cement was introduced in the interior of the channel and condensed with titanium Easy ${ }^{\circledR}$ capacitors in green, black, yellow and blue. Preparation was also made for pin installation, temporary restoration of Meron $R \AA$ glass ionomer and final radiography (Figure 2). It was prescribed Amoxicillin 500.0mg every 8 hours for 7 days, Dexamethasone $4 \mathrm{mg}$ every 12 hours for 3 days and Dipirone Sodium 500.0mg every 6 hours if there was pain. The patient was referred to the Restorative Dentistry clinic of the same institution and 1 week after installation of FGM ${ }^{\circledR}$ fiberglass pin with cement Cement Resinoso Dual RelyX U200 Automix - 3M®. Restoration of Charisma Kulzer ${ }^{\circledR}$ resin with Radi ${ }^{\circledR}$ photopolymerizer was carried out. After 6 months, a clinical and radiographic examination was performed. The absence of clinical signs and symptoms and repair of the periapical lesion were observed through radiographic examination. Integrity of the hard blade was verified by the continuity of the periodontal ligament in the periapical region (Figure 3).

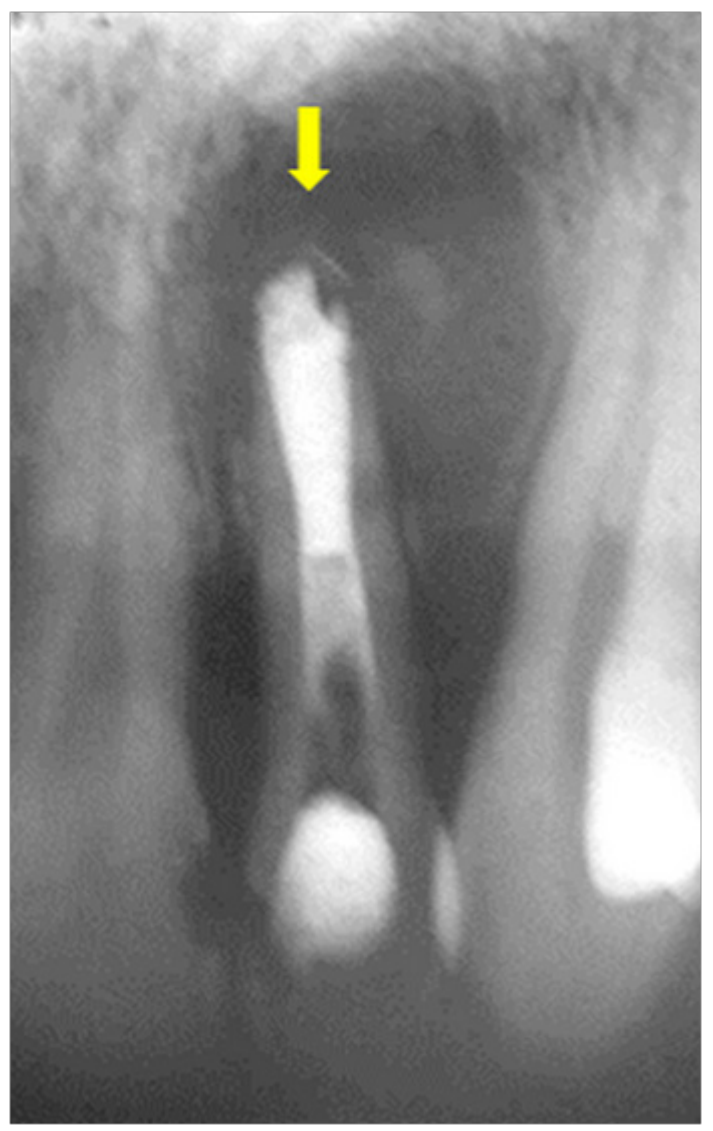

Figure 2 Final tooth radiography 2.2 . 


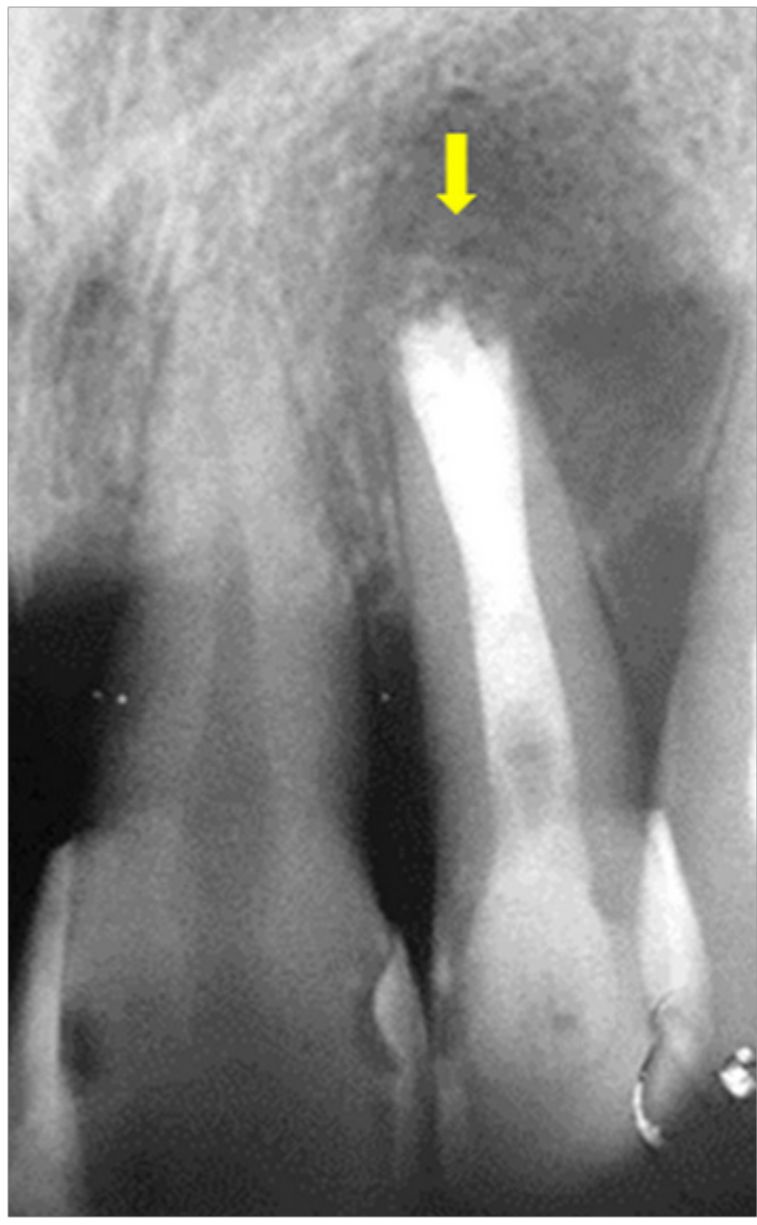

Figure 3 Radiography of preservation 6 months after tooth treatment 2.2 .

\section{Results}

PBS ${ }^{\circledR}$ HP cement has determined regeneration of periapical tissues, 2.2 tooth regeneration occurred, and may be indicated as a synthetic barrier in necrotic teeth with incomplete rhizogenesis, according to Figure 1, Figure 2 and Figures 3.

\section{Discussion}

The present case report refers to a 36-year-old patient who suffered trauma when she was 10 years old. During the subsequent twentysix years, there was no clinical manifestation of necrosis, which occurred following the trauma. The patient reported the occurrence of fistula after episode of systemic problem at 36 years. The pathology was diagnosed and treatment was indicated. Necrosis due to trauma in teeth with incomplete rhizogenesis is predicted in adult patients with a history of trauma. ${ }^{1}$ Patient $\mathrm{F}$ fell into the classification of Cvek IV equivalent to open apical foramen presenting almost complete root length and necrosis with presence of periapical lesion. ${ }^{5}$ There are discussions about teeth with incomplete rhizogenesis in adult patients, due to the fact that few studies exist on the root development stage regarding the frequency of teeth with open apices and necrotic pulp. ${ }^{6}$ The present study demonstrated that the endodontist needs expertise to diagnose and treat cases of age-independent incomplete rhizogenesis. The frequent question of the endodontists is: how a tooth in these conditions remained in function for 26 years without symptomatology? There are several factors capable of modifying the behavior of the immune system, such as age, genetic, metabolic, environmental, anatomical, physiological, nutritional and microbiological factors. ${ }^{20,21}$ Immunologically compromised middleaged individuals are more susceptible to infections, which is related to limited immunological capacity in these age groups. ${ }^{22-24}$ Studies have shown that these conditions are related to certain levels of susceptibility to certain infections. ${ }^{24}$ This case report associated with age and systemic development of chronic problem exacerbation that may be linked to immunological conditions. The need for clinical and mainly radiographic evaluation is a basic factor for performing semiology in middle-aged patients. The presence of fistula in the clinical examination and periapical lesion, analyzed by radiography was essential for structuring the proposed treatment protocol, which involved chronic periapicopathy in a tooth with incomplete rhizogenesis. ${ }^{11}$ The treatment of pathologies as described requires minutiae because the situation involves the patient in a systemic way. Modern Endodontics provides implementation of protocols that do not depend on time and complexity of techniques. The current endodontic interventions are able to rehabilitate situations such as those reported in this control case. Instrumentation using engines that reciprocate with "cutting edge" instruments such as those used, provide less traumatic working conditions. The Prodesign Logic Easy ${ }^{\circledR}$ instrument provided conditions to perform the work, without risks to the fragile root. The disinfection procedures also corroborated the success of the treatment, since the ultrasonic and chemical action with the use of surfactant EDTA and hypochlorite, provided productive disinfection of the dental element. However, the use of techniques such as calcium hydroxide apexification could be negative for treatment success. ${ }^{12}$ Therefore, in addition to the above-mentioned conditions, the limitations of conventional techniques using guttapercha cones in $70.0 \%$ of the fillings and cements that complement the fillings are precarious regarding the requirements necessary for delicate cases as described. The proposed use of synthetic apical barriers determines innovative alternatives to obturate channels with necrosis and incomplete rhizogenesis. ${ }^{13}$ The use of cements such as PBS ${ }^{\circledR}$ HP (single element) in obturation determined alternative to the traditional method of treatment of necrotic teeth with incomplete rhizogenesis. ${ }^{13}$ This cement presents basic requirements, such as: hermetic sealing, biocompatibility, bioactivity with the formation of carbonated apatites that promote biomineralization. ${ }^{25}$ This case report demonstrated that the immediate filling in the treatment of teeth with incomplete rhizogenesis necrosed determines a favorable result when using biocompatible and bioactive cements as the cement PBS ${ }^{\circledR} \mathrm{HP}$ (single element) in obturation.

\section{Conclusion}

PBS ${ }^{\circledR}$ HP cement has determined regeneration of periapical tissues and may be indicated as a synthetic barrier in necrotic teeth with incomplete rhizogenesis.

\section{Acknowledgements}

None.

\section{Conflict of interest}

None. 


\section{References}

1. Flanagan TA. What can cause the pulps of immature, permanent teeth with open apices to become necrotic and what treatment options are available for these teeth. Aust Endod J. 2014;40:95-100.

2. Torabinejad M, Abu-Tahun I. Management of teeth with necrotic pulps and open apices. Endod Topics. 2010;23(1):105-30.

3. Seghi RR, Nasrin S, Draney J, et al. Root fortification. $J$ Endod. 2013;39:S57-S62.

4. Nuni E. Chapter 8: Pulp therapy for the young permanent dentition. In: Fuks AB, Peretz B, editors. Pediatric endodontics. Current concepts in pulp therapy for primary and young permanent teeth. Switzerland: Springer;2016: 120.

5. Lam R. Epidemiology and outcomes of traumatic dental injuries: a review of the literature. Aust Dent J. 2016;61:S4-S20.

6. Andersson L. Epidemiology of traumatic dental injuries. $J$ Endod. 2013;39(3 Suppl):S2-S5.

7. Andreasen JO, Farik B, Munksgaard EC. Longterm calcium hydroxide as a root canal dressing may increase risk of root fracture. Dental Traumatol. 2002;18(3):134-7.

8. Sousa-Neto MD, Santos ES, Estrela C, et al. Treatment of middle-apical level root fracture in necrotic teeth. Aust Endod J. 2000;26:15-8.

9. Safi L, Ravanshad S. Continued root formation of a pulpless permanent incisor following root canal treatment: a case report. Int Endod J. 2005;38(7):489-93

10. Sasaki H. Relação entre hipertensão e lesão periapical: estudo in vitro e in vivo. Braz. oral res. vol.30 no.1 São Paulo; 2016.

11. Consolaro A. Dentes com lesão periapical crônica diagnosticada e tratada durante o tratamento ortodôntico: quando retornar a aplicação de forças? Rev Clin Ortodon Dental Press Maringá. 2008;7(1):109-111.

12. Bakland LK, Andreasen JO. O agregado de trióxido mineral substituirá o hidróxido de cálcio no tratamento de complicações de cicatrização pulpar e periodontal após traumatismo dentário? Uma revisão. Dent Traumatol. 2012;28:25-32.

13. Holden DT, Schwartz SA, Kirkpatrick TC, et al. Resultados clínicos das barreiras artificiais de extremidade da raiz com agregado de trióxido mineral nos dentes com vértices imaturos. J Endod. 2008;34:812-7.
14. Bhagavaldas MC, Diwan A, Kusumvalli S, et al. Efficacy of two rotary retreatment systems in removing Gutta-percha and sealer during endodontic retreatment with or without solvent: A comparative in vitro study. J Conserv Dent. 2017;20(1):12-16.

15. Gandhi B, Halebathi-Gowdra R. Comparative evaluation of the apical sealing ability of a ceramic based sealer and MTA as root-end filling materials - An in-vitro study. J Clin Exp Dent. 2017;9(7):e901-e905.

16. Silva Neto JD, Brito RH, Schnaider TB, et al. Root perforations treatment using mineral trioxide aggregate and Portland cements. Acta Cirurgica Brasileira. 2010;25(6):479-84.

17. Silva Neto JD, Schnaider TB, Gragnani A, et al. Portland cement with additives in the repair of furcation perforations in dogs. Acta Cirurgica Brasileira. 2012;27:809-14.

18. Silva SR, da Silva Neto JD, Veiga DF, et al. Portland cement versus MTA as a root-end filling material. A pilot study. Acta Cirurgica Brasileira. 2015;30(2):160-4.

19. Silva SR, Silva JD Neto, Schnaider TB, et al. The use of a biocompatible cement in endodontic surgery. A randomized clinical trial. Acta Cirurgica Brasileira. 2016;31(6):422-7.

20. Bellanti JA. Immunology III. Philadelphia: Saunders; 1985.

21. Prieto A, Pérez A, Reyes E, et al. Tolerancia y autoinmunidad. Medicine. 1997;51:2303-8.

22. Prieto A, Pérez A, Reyes E, et al. Moléculas coestimuladoras, tanto solubles como de membrana implicadas en la presentación antigénica y en la respuesta inmune. Medicine. 1997;51:2255-62.

23. Alés Martínez J, Alvarez-Mon M, Merino F, et al. Decreased TcR $\mathrm{CD} 3+$ cell numbers in healthy aged humans. Evidence that $\mathrm{T}$ cell defects are masked by a reciprocal increase in TcR CD3 CD+ natural killer cells. Eur J Immunol. 1988;18(11):1827-30.

24. Watson RR, Eisinger M. Exercise and disease. Boca Raton: CRC; 1992.

25. Torabinejad M, Parirokh M, Dummer PMH. Mineral trioxide aggregate and other bioactive endodontic cements: An updated overviewPart II: Other clinical applications and complications. Int Endod J. 2018;51(3):284-317. 